\title{
Erratum to: TNF- $\alpha$ induces MMP-9 expression and soluble ICAM-1 release via TRAF2, c-Src, MAPKs and NF-KB in osteoblast-like MC3T3-E1 cells
}

Tsai Chia-Lan ${ }^{1}$, Wei-Chung Chen ${ }^{1}$, Hsi-Lung Hsieh² ${ }^{2}$ Pei-Ling Chi ${ }^{1}$, Li-Der Hsiao ${ }^{1}$ and Chuen-Mao Yang ${ }^{1,3^{*}}$

\section{Erratum}

It has come to our attention that Figures $2 \mathrm{~F}$ and $7 \mathrm{~A}$ in our article [1] are the same as Figures $1 \mathrm{E}$ and $6 \mathrm{~A}$ in our previously published article in Bone [2] and there is some text overlap in the Methods section. Both papers approached the various intracellular signalling pathways involved in TNF- $\alpha$-induced MMP-9 expression in osteoblast-like MC3T3-E1 cells, which shared common signalling molecules such as Src and p42/p44 MAPK. The images presented come from the same experiment described in both articles. Due to the similar approach used in each case there is text overlap in the Methods section. We apologize for this overlap and any inconvenience caused.

\section{Author details \\ ${ }^{1}$ Department of Physiology and Pharmacology and Health Ageing Research Center, College of Medicine, Chang Gung University, Tao-Yuan, Taiwan. ${ }^{2}$ Department of Nursing, Division of Basic Medical Sciences, Chang Gung University of Science and Technology, Tao-Yuan, Taiwan. ${ }^{3}$ Department of Physiology and Pharmacology, Chang Gung University, 259 Wen-Hwa 1st Road, Kwei-San, Tao-Yuan, Taiwan.}

Received: 26 January 2015 Accepted: 26 January 2015 Published online: 20 March 2015

\section{References}

1. Tsai CL, Chen WC, Hsieh HL, Chi PL, Hsiao LD, Yang CM. TNF-a induces MMP-9 expression and soluble ICAM-1 release via TRAF2, c-Src, MAPKs and NF-KB in osteoblast-like MC3T3-E1 cells. J Biomed Sci. 2014;21:12.

2. Tsai CL, Chen WC, Lee IT, Chi PL, Cheng SE, Yang CM. C-Src-dependent transactivation of PDGFR contributes to TNF-a-induced MMP-9 expression and functional impairment in osteoblast-like MC3T3-E1 cells. Bone. 2014;60:186-97.

\footnotetext{
* Correspondence: chuenmao@mail.cgu.edu.tw

'Department of Physiology and Pharmacology and Health Ageing Research Center, College of Medicine, Chang Gung University, Tao-Yuan, Taiwan ${ }^{3}$ Department of Physiology and Pharmacology, Chang Gung University, 259 Wen-Hwa 1st Road, Kwei-San, Tao-Yuan, Taiwan
}

\author{
Submit your next manuscript to BioMed Central \\ and take full advantage of: \\ - Convenient online submission \\ - Thorough peer review \\ - No space constraints or color figure charges \\ - Immediate publication on acceptance \\ - Inclusion in PubMed, CAS, Scopus and Google Scholar \\ - Research which is freely available for redistribution
}

Submit your manuscript at

www.biomedcentral.com/submit

( BioMed Central

\section{() Biomed Central}

(c) 2015 Chia-Lan et al.; licensee BioMed Central. This is an Open Access article distributed under the terms of the Creative Commons Attribution License (http://creativecommons.org/licenses/by/4.0), which permits unrestricted use, distribution, and reproduction in any medium, provided the original work is properly credited. The Creative Commons Public Domain Dedication waiver (http://creativecommons.org/publicdomain/zero/1.0/) applies to the data made available in this article, unless otherwise stated. 